DOI 10.18699/SBB-2020-67

\title{
Идентификация регуляторного гена, контролирующего синтез кутикулярного воска ячменя
}

Колосовская Е.В. ${ }^{1,2 *}$, Герасимова С.В. ${ }^{1,2}$, Короткова А.М. ${ }^{1}$, Хертиг К. ${ }^{3}$, Морозов С.В. ${ }^{4}$, Черняк Е.И. ${ }^{4}$, Домрачев Д.В. ${ }^{4}$, Кочетов А.В. ${ }^{1,2}$, Кумлен Й. ${ }^{3}$, Хлесткина Е.К. ${ }^{1,2,5}$

${ }^{1}$ Институт цитологии и генетики СО РАН, Новосибирск, Россия

${ }^{2}$ Новосибирский государственный университет, Новосибирск, Россия

${ }^{3}$ Институт генетики растений и исследований культурных растений, Германия, Гатерслебен

${ }^{4}$ Новосибирский институт органической химии СО РАН, Новосибирск, Россия

${ }^{5}$ Всероссийский институт растениеводства имени Н. И. Вавилова, Санкт-Петербург, Россия

*e-mail: e.kolosovskaia@g.nsu.ru

Ключевые слова: ячмень, Hordeum vulgare, Cas9/gRNA, эпикутикулярный воск, обратная генетика

Мотивация и цель: Сайт-специфический мутагенез открывает новые перспективы для решения проблем обратной генетики. Одно из направлений в этой области - использование системы Cas9/gRNA для изучения функций регуляторных генов. В настоящей работе в качестве мишени был выбран ген ячменя (Hordeum vulgare) подсемейства WIN1/SHN1, кодирующий транскрипционный фактор, который участвует в формировании устойчивости к биотическому стрессу. Этот ген принадлежит к семейству APETALA2 / Ethylene Responsive Factor (AP2/ERF), играющему роль в процессах роста, развития, реакции на стресс. Целевой нокаут гена HvWIN1/SHN1 привел к рецессивному фенотипу дефицита кутикулярного воска.

Meтоды и алгоритмы: Первичные (M1 = T0) мутанты ячменя (сорт «Golden Promise») были получены путем целевого нокаута гена HvWIN1 с использованием системы Cas9/gRNA. Шесть линий без Т-ДНК, несущие различные гомозиготные мутации были отобраны в поколении М4. Ультраструктуру и биохимический состав воска исследовали с помощью сканирующей электронной микроскопии и газовой хроматографии в сочетании с масс-спектрометрией.

Результаты: Микрофотографии и измерения воска показали, что мутантные растения и растения дикого типа накапливают одинаковое количество воска на листовых пластинках. Напротив, воск листовых влагалищ мутантных растений заметно отличается от такового у дикого типа как по общему количеству, так и по составу отдельных компонентов, включая алканы, спирты и дикетоны. Заключение: Природа мутантного фенотипа и полученные данные позволяют предположить, что транскрипционный фактор HvWIN1/SHN1 в норме регулирует синтез кутикулярного воска на поверхности влагалищ верхних листьев ячменя.

Благодарности: Работа поддержана грантом РНФ 16-14-00086. Работа выполнена на оборудовании ЦКП «Микроскопического анализа биологических объектов» Центрального Сибирского ботанического сада СО РАН (Новосибирск, Россия). 